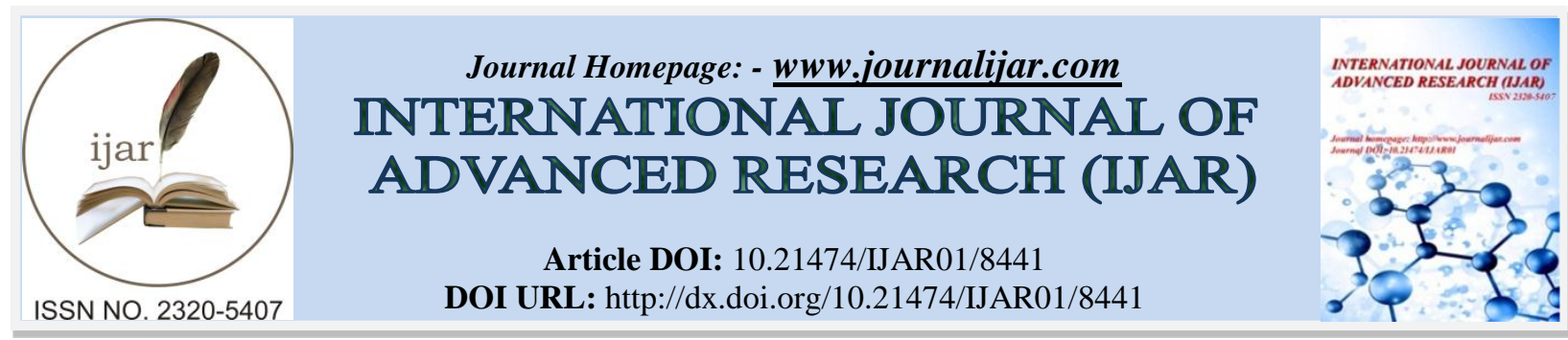

RESEARCH ARTICLE

\title{
PROSOCIAL BEHAVIOUR IN THE FRAME OF LOCAL WISDOM : CASE STUDY OF BEHAVIOUR OF VILLAGE OFFICIALS IN A BUDGET PERSPECTIVE.
}

1. Accounting Departement, Hasanuddin University.

\section{Rahmi Triyulin $^{1}$, Syarifuddin ${ }^{2}$ and Tawakkal ${ }^{2}$.}

2. Accounting Departement, State polytechnic of Ujung Pandang.

\section{Manuscript Info}

Manuscript History

Received: 20 November 2018

Final Accepted: 22 December 2018

Published: January 2019

Key words:-

Prosocial behaviour, local wisdom, village head, village funds budgeting.

\section{Abstract}

This study aims to examine how the Village Head interpret prosocial behaviour in the Village Fund budgeting. The phenomenology methodology with the Bastem community's local wisdom approach, namely obedience and mutual cooperation derived from Bastem's life philosophy "Sangrodoan Tinting; Sang Tirimbakan Pajo-pajo; Sang Innonian La'pa-la'pa". The results founded the Salubua Village Head had 3 social capital is social stratification, leadership style and prosocial behaviour which were reflections of the obedience and mutual cooperation between society and their leaders. Village Head interpreted prosocial behaviour as manifested in the Village Fund budgeting in the education, health and poverty alleviation programs.

Copy Right, IJAR, 2018,. All rights reserved.

\section{Introduction:-}

The overall development of the center, region and village is one of the important agendas of the Jokowi government listed in the third Nawacita, which reads, "Building Indonesia from the periphery by strengthening regions and villages ...". Development which has always been oriented in urban areas is now behind rural areas. Village development Based on the Village Regulation Number 6 of 2014 is "efforts to improve the quality of life and life for the welfare of rural communities". Village Development according to the Village Regulation article 78 paragraph (1) aims to improve the welfare of the village community and the standard of living and poverty reduction through meeting basic needs, building village facilities and infrastructure, developing local economic potential, as well as sustainable use of natural and environmental resources ". To achieve the objectives of village development, the central government allocates a number of funds transferred to the Village through the regional general cash account in the form of the Village Fund Program. The amount of funds allocated to villages is increasing every year, which in the 2018 state budget stipulation has been set at 60 trillion plus the balance funds received by the district / city government at least 10\% after deducting special allocation funds called Village Fund Alocation. Of course with such a number raises concerns about the management and utilization. so that "it is predicted" various policies and regulations to accommodate all village problems in order to achieve village development goals.

In public organizations as well as business processes we recognize the existence of a budget cycle that starts from the stages of planning, preparation, implementation, reporting and evaluation. In this case the focus of research is the budgeting planning process in the village. So strategic is the budgeting process, sometimes we forget that behind these strategic decisions there is a decisive actor in laying policies and allocating resources which is actually an intellectual reflection of the actor himself. "The budget is the face and heart of the perpetrators of policy making 
government, namely the Village Head. When a leader has the power to plan and determine a public policy is very closely related to the behavior of policy makers, so that the direction and objectives of the budgeting process can be achieved, of course it is expected that the policies regulated in the law regarding the duties of village heads are prosocial.

Prosocial behaviour is interpreted as behavior or action to help others without expecting rewards from people who are helped, without pressure and coercion. This behaviour is part of the values of local wisdom of the local community. Obviously in the context of village budgeting, it is expected that the behaviour of village budget compilers in taking the direction of policies and allocation of resources prioritizes the interests and welfare of the village community. "The basic ideology of public organizations, especially government, is to maximize social welfare by prioritizing the public interest and service to the community above other interests" (Damayanti, 2009). Prosocial behaviour of village officials in setting village budgets should also refer to the spirit of local wisdom of local communities that are internalized within budgetary actors. Prosocial behavior that collaborates with the value of the local wisdom of the Luwu community is leverage that can encourage budgetary actors to take action so that it can have an impact on the welfare of the community.

However, the recent phenomenon is the number of reports of alleged deviations from village fund management delivered by the Chairperson of the Village Fund Task Force, Bibid Samad Riyanto at the National Coordination Meeting on Corruption Fighting Movement (GMPK) quoted from (Republika.news, 24/11/2011) as many as 10,922 reports and as a follow up report but submitted to the police or prosecutor's office to be followed up legally. The number of indications of fraud that is quite significant is indicated by the large number of Village Heads as political actors who are included in the "legal realm" due to the misuse of the Village Fund budget, of course, the political situation and dynamics both within themselves and the situation surrounding the budgetary actors.

The above phenomenon is the starting point, researchers are interested in exploring the behavior of actors in village financial management focused on the planning process in village budgeting, with a village typology which is a remote village. In addition, research has never been carried out on the budgeting of Village Governments in the Bastem Region. The budgeting planning process is important because at this stage of the process all activities and wheels of government begin. This stage is the determination of priorities from the direction of village development, whether it is prosocial or depends on the interests of the budgeting actors themselves. Based on the phenomenon of the behavioral impact of the Village Head on the use of Village Funds this study aims to understand and examine how Village Heads interpret prosocial behaviour in the Village Fund budgeting.

\section{Methodology:- \\ Phenomenology and Local Wisdom}

In this study using a local wisdom approach in mapping the planning process in village budgeting towards the meaning of the prosocial behavior of the village head. Research on the extraction of the value of local wisdom of the Luwu community was carried out in the Bastem community, which has a life philosophy namely "Sangrodoan Tinting; Sang Tirimbakan Pajo-pajo; Sang Innonian La'pa-la'pa" "which means" mutual cooperation and mutual assistance". Or in other words the Bastem community prioritizes common interests, cooperates in alleviating a problem and obeys all the sayings of the leaders or traditional elders regarding customary rules and social rules according to Hamdat (2016).

Phenomenology research according to Creswell (1994) describes the general meaning of a number of individuals towards their various life experiences related to concepts or phenomena. The use of the transcendental phenomenology approach because the researcher considers the budgeting process is a social phenomenon compiled by the existence of social interactions between various parties and researchers want to see firsthand how the meaning of each individual / informant subjectively about prosocial policy in the frame of local wisdom.

\section{Method of collecting data}

The method of data collection in this study uses primary data and secondary data. Primary data obtained from interviews, observation and documentation. The interview is an in-depth data collection on the objects of research, namely the Village Heads, village officials and the Bastem community in relation to the research. Data collection by observation is done by unstructured observation method, meaning that observations are carried out without using observation guides, where researchers must be able to develop their observational power in observing an object of research. Data collection with documentation is the process of finding data in the form of documents, notes, 
transcripts, books, newspapers, journals, magazines and so on. While secondary data is obtained from data from the researchers' review of documents related to related research in the form of softcopy and hardcopy.

This research is located in Salubua Village, Bastem Utara Subdistrict, Luwu Regency, South Sulawesi Province, which is part of the Basse Sang Tempe community or known as the Bastem community. The Bastem community is part of the ancient Luwu kingdom using Toraja as an everyday language, because of its geographical location which is directly adjacent to Tana Toraja Regency. The location of this village is based on the first, this village is a category of remote villages; second, the village is located in Tanah Bastem, where cultural customs and local wisdom are still thick; and Third, the Village is led by the Village Head who has served for 3 periods, so that it is closely related to community perceptions of the behavior of the Village Head.

\section{Analysis Techniques}

The phenomenological data analysis technique used in this study is based on Edmund Husserl's thoughts, namely Epoche, Noema, Noesis, Intentional Analysis, and Eidetic Reduction. In this study the data were tested for validity using data triangulation, or checking data from various sources in various ways (techniques) and time. The researcher validates the data by source triangulation, which uses several sources of information to filter, adjust and strengthen data, both in a variety of different data collection methods (interviews, observation, documentation) and using supporting informants.

\section{Results And Discussion:-}

Internalization of the Local Wisdom Values of the Bastem Community

The meaning of Prosocial Behaviour as part of the local wisdom of the Bastem community that comes from the living philosophy of "Sangrodoan Tinting; Sang Tirimbakan Pajo-pajo; Sang Innonian La'pa-la'pa" "which means" mutual cooperation and mutual assistance" means that the people of Bastem look after each other, help each other with sincerity and all souls as an inseparable unity groups, castes and beliefs and submissive and obedient under the leadership of policy makers namely adat leaders, village heads and BPD elements.

The philosophy of life of the Bastem community that puts forward the attitude of helping and maintaining each other's integrity is in line with the meaning of Prosocial Behaviour raised in this research, which is helping others without strings attached and without coercion. So it can be concluded that prosocial behaviour itself is part of the value of the local wisdom of the Bastem community.

\section{Village Development Planning}

The Minister of Internal Affairs Regulation Number 114 of 2014, concerning the Village Development Guidelines which contain that "Village Development Planning is the process of the stages of activities organized by the Village Government involving the BPD (Village Consultative Body) and all elements of the community in a participatory manner to utilize and allocate village resources in order to achieve village development goals ".

Village Planning and Development is carried out by the Village Government in a participatory manner involving all elements of the village community in a spirit of mutual cooperation. Participatory development is a development management system in the village and rural areas which is coordinated by the Village Head by promoting togetherness, kinship, and mutual cooperation to realize welfare and social justice for the village community.

In the process of planning, budgeting and implementing Village development, the Village Government is accompanied and guided by the District / City Government which is technically implemented by the District Apparatus Organization which is the leading sector in Village assistance, for example the DPMD in the Luwu Regency area and coordinates with the Camat in area of each village. In addition, in the planning and budgeting process, the Village Head can be accompanied by professional assistants, village community empowerment cadres, and / or third parties according to existing regulations in analyzing and preparing Village development plans in accordance with their authority under the Village Law.

Village Development based on the Village Regulations Number 6 Year 2014 consists of the field of implementation of village governance, implementation of village development, village community development and empowerment of village communities. Village development planning arranged in time includes:

1. Village Medium Term Development Plan (RPJMDes) for a period of 6 (six) years; and 
2. The Village Annual Development Plan or the so-called Village Government Work Plan (Village RKP) for a period of 1 (one) year.

\section{Prosocial Behavior in Village Budgeting Planning}

In the Village Regulations Number 6 of 2014, contained in article 78 regulates the three objectives of village development, namely improving the quality of human life, improving welfare and poverty reduction. The three development goals become the foundation of thinking in each stage of development starting from the planning, implementation and supervision stages. Whereas the development objectives of the Village itself will be realized through five priorities for using Village funds, namely:

1. Meeting Basic Needs;

2. Development of Village Facilities;

3. Village Infrastructure Development;

4. Local Economic Development and

5. Natural Resource Utilization and Sustainable Environment.

Besides that contained in Article 80 of the VillageRegulations also places an increase in quality and access to basic services as the main thing in determining the priorities, programs, activities, and needs of Village Development formulated in the Village Development Planning Meeting. So in order to fulfill the basic needs of the village community, policy makers must prioritize basic social services in the fields of education, health, empowerment of women and children, and empowerment of marginalized communities and members of the village community with disabilities.

The researcher tried to explain the meaning of prosocial behavior of the Head of Salubua Village in order to fulfill the basic needs of the community related to education, health and to improve the standard of living of the people who had or had not been accommodated in the Village Budget of Salubua.

\section{Prosocial Behavior in Education Budgeting}

Education is the most crucial thing in the order of life of the nation and state, with education will create superior seeds in regenerating political leadership potential natural resources in a nation and country. "The education sector is a sector that must get attention and priority because it is the root of an order of change in political culture" (Syarifuddin: 2009).

The implementation of the education sector's partisanship in the budgeting process in Salubua Village can be seen from the planning in the Village Musrenbang and Village Deliberations contained in the APBDes of the 2018 budget year, which the researchers are trying to map, as below:

Table 1:-Budgeting for the Education Sector in the 2018 Regional Budget

\begin{tabular}{|l|l|l|l|}
\hline No & Proposal & Amount Fund & Source Funds \\
\hline 1 & Training / Course & $5.000 .000,00$ & Village Funds \\
\hline 2 & Taman Bacaan & $4.800 .000,00$ & Village Funds \\
\hline 3 & Pembangunan SMK & $20.000 .000,00$ & The Remaining Budget \\
\hline
\end{tabular}

Source: Field data processed in 2018

The researcher tried to examine the budgeting structure of Salubua Village in the education sector by using Village Funds which were very small in amount of only Rp.9,800,000.00 or $1 \%$ of the total Village Funds distribution of Rp730,854,000.00, with the remainder entirely being used for village development in the form of road infrastructure development. The education budget that is "only" $1 \%$ is intended to provide training and English language courses in the village of Salubua.

The researcher tried to understand the actor's thoughts when formulating these very minimal educational plans, as revealed by the Head of the Salubua Village as below:

"Indeed, I admit since the Village Fund was rolled out by me and the villages in Bastem to prioritize the development of village infrastructure, namely roads and bridges are preferred because as we know, it is very worrying access roads to Bastem, the lack of distribution of Village Funds to the education sector does not mean I I was blind to the needs of the community in education, instead I was fighting for the existence of schools from 
elementary, junior high and vocational schools in the village of Salubua. But you need to know that the use of the Village Fund for education is very limited and cannot even be a basic funding for the development of quality education in the village. Only limited to additional funds for the development of education and improvement of educational facilities and infrastructure. "

The epocher's research question is "Why is there so little budgeting in the education sector from the Village Fund?" Based on interviews and observations it is known that the education sector budgeting in the village of Salubua is very small because it prioritizes the construction of roads and bridges. limited (noema). This is because the budgeting of the Village Fund focuses on the development of village infrastructure in addition to the priority of using the Village Fund for the education sector in the Village Law number 6 of 2014 (noesis).

In the Village Law Number 6 Year 2014 contains the use and management of Village Funds in the development, utilization and maintenance of educational and cultural facilities and infrastructure, including:

1. Community reading park;

2. Early childhood education programs;

3. Community training / learning center;

4. Development and development of art studios; and

5. Other education and training facilities and infrastructure in accordance with the conditions of the Village.

It is clearly stated in the Village Law that the construction of schools which are basic needs is not imposed because it is the authority of the Ministry of Education. So that budgeting for the education sector, which is only $1 \%$ of the total Village Fund distribution due to the priority of the Village Fund in the education sector according to the Village Law, cannot be fully implemented in Salubua Village besides that the geographical condition of the remote Salubua Village and road accessibility is very alarming. focusing on repairing roads or connecting lines.

Back in Table 1 about the education sector budgeting discussed in the Village Conference, there was assistance with the construction of the Christian Vocational High School which originated from SILPA the previous year. The construction of school infrastructure is not accommodated by Village regulations, but the urgent need for the existence of schools "forces" them to establish the establishment of SMKs which are initially self-reliant from the community of the Village of Salubua.

Their struggle was not in vain, since a year ago they succeeded in establishing a vocational school with 35 students from the villages of Salubua themselves and surrounding villages and the number of teachers as many as 6 people. This Christian Vocational School focuses on vocational workshops and mechanics which are considered majors that are quite familiar to the children of the Village of Salubua who want to migrate and complain about their fate in other areas.

With the condition of buildings that are still "makeshift", the Head of Salubua Village to this day is still fighting for the development and procurement of school facilities and infrastructure by sending proposals for assistance to the Foundation and parent and government agencies that have the authority to obtain assistance, in this case or Luwu.

However, based on a search of the SMK development researchers, some of them used SILPA Village funds the previous year which were not used or had not been allocated, such as excerpts of interviews with the Head of Salubua below:

"Priority for the use of the Village Fund is not permitted to use Village Funds in School Construction, so I did not use the Village Fund to help with the construction of SMKs but from last year's SILPA funds, and as soon as I did, there were no rules governing the use of SILPA, am I wrong Ma'am Because of that, Mom, I dare to use the funds and the Inspectorate is also not a finding because this is a basic need of our Village community, and I am willing to be responsible for the use of these funds. "

It is known in Permendagri 113 in 2014 regulated the use of SILPA namely to cover the budget deficit, to finance further activities and fund other obligations that have not been resolved until the end of the year. So there was no explicit regulation of the types of activities for the use of SILPA funds the previous year.

Based on interviews and observations it is known that the Head of the Salubua Village uses SILPA funds to help build Christian Vocational Schools in Salubua Village (noema). This is because the budgeting of the Village Fund 
for the education sector in Village Law number 6 of 2014 is not allowed to build school infrastructure (noesis). The Village Head of Salubua considers that the School is a form of basic fulfillment of his community, community welfare is directly proportional to the level of education of the community in his village

Eideitic reduction that can be abstraction from the phenomenological study of the statements of several informants above is a form of manifestation of prosocial behavior by the Head of the Salubua Village in the planning of the education sector budgeting. The behavior of the Gessong as the Head of Salubua in fighting for education for the community in the two excerpts of the interview above is a form of prosocial behavior that prioritizes the interests of the people without the sake of changing living standards to be more feasible. Although it is possible that in this prosocial manifestation there are some rules that are violated or the rules are still "gray" and multi-interpretations such as the use of SILPA Funds for school construction.

\section{Prosocial Behavior in Health Budgeting}

Health is a form of basic social service. It is very ironic if the Village Fund which has been disbursed by the central government every year in large enough amounts flows to the village treasury but is still found in villages where the population is far from the word "healthy life" with indications of malnutrition, disease-prone people, high rates maternal and child deaths and other forms that indicate a lack of health management and a lack of knowledge about healthy living by the villagers.

Talking about health is closely related to the level of community education, why? Villages with highly educated communities tend to receive information more quickly and understand the need for a healthy life. Whereas people with low levels of education are constrained by the level of understanding in processing information or the ability to read the instructions given by health educators or medical personnel on the importance of healthy living.

Health budgets in remote villages should be a priority because "prevention is better than cure" is a mandatory slogan in the village to avoid "medical accidents", meaning a health emergency in a region or village that cannot be addressed by the medical medical department because of its location out of reach of health services, inadequate aspects of village road transportation that make it difficult for medical personnel to reach people with disease.

The accommodation of the health sector in budgeting in the Salubua APBDes can be seen from the proposed program of planning activities in the Village Musrenbang and Village Deliberations for fiscal year 2018, which the researchers tried to map, as below:

Table 6.6:-Budgeting for the Health Sector in the 2018 Regional Budget

No Activity Amount of Fund Source Funds

1 Posyandu Cadre 4,020,000,00 Village Funds (APBDes)

2 MCK 3,000,000.00 Village Funds (APBDes)

Source: Field data processed in 2018

Based on the excerpts of the interview with the Head of the Salubua Village, there is a statement from the Village Chief which is the epoche as below:

"This has become a separate thanksgiving, in the midst of this remote village, there are still medical personnel who are willing to devote themselves. I as the Village Head is so helped that I can focus more on the problem of water supply constraints as well as the provision of MCK budgeted in the use of the Village Fund sector health ".

Health budgeting is one of the manifestations of the government Need for the basic needs of the village community for the creation of development, utilization and maintenance of health facilities and infrastructure based on Law Number 6 Year 2014, including:

1. Clean water at village scale;

2. Environment sanitation;

3. Village health services such as posyandu; and

4. Other health facilities and infrastructure in accordance with the conditions of the Village.

In Salubua Village there is a Poskesdes located next to the Village Head's office. This poskesdes is guarded every day by a village midwife who comes every two weeks. Indeed, it has been a problem since the past was the placement of health workers who were not evenly distributed in all regions, because of the lack of a number of 
health workers, and the maternal and infant mortality rates were still quite high. The solution taken by the central and regional governments is to gradually increase the number of health workers, improve partnerships between midwives and traditional birth attendants, conduct self-help activities and carry out non-medical perinatal maternal audits in the sub-districts.

Posyandu activities have been started for years, before the Village Fund program, so that health workers in the village who work together with the Kecamatan Health Center are not too difficult to provide information on the importance of the health of infants and toddlers through immunization and measles, as well as periodic examinations conducted at Poskesdes .

The behaviour of the Village Chief in interpreting prosocial budgeting in the health sector focuses on honorariums for medical staff (midwives), procurement of clean water and MCK which are priorities in the use of Village Funds budgeted for APBDesa 2018 (noema) showing the initiative of the Village Head in the health sector in the use of the Village Fund which focuses on improving maternal and child health, providing clean water through Appropriate Technology as well as the construction of MCK in people's homes in stages (noesis). So that from the statement of the Village Head, Eideitic reduction that the researcher can abstraction from the phenomenology study above is a form of manifestation of prosocial behavior by the Head of Salubua Village in planning the budgeting of the health sector.

\section{Prosocial Behavior in Budgeting for Poverty Alleviation in Rural Communities}

Poverty alleviation and improvement of living standards of the village community are the main objectives of village development so that the central government is willing to pour funds up to billions of rupiahs, as well as the mandate of the 3rd Nawacita namely marginal budgeting in remote villages, a milestone in changes in planning reform and budgeting.

The formula allocation (AF) used by the central government is the Village Fund distribution formula that takes into account the condition of the Village, namely the population, the number of poor people, the area, and the geographical difficulty level of the Village. Correlation of village fund distribution with the number of poor villagers and the Geographic Difficulties Index (IKG) shows that the distribution of the Village Fund is still not equitable.

Villages with high poverty rates and difficult geographical conditions actually get Village Funds that are relatively equal or smaller compared to villages where the number of poor people is lower and the level of geographical difficulties is easier. Therefore, reformulating the distribution of village funds is very important to do by enlarging the portion of AF so that the use of village funds is more effective in alleviating poverty and increasing community access to public services through the development and empowerment of village communities.

In addition to the Village Fund allocation which has not been equitably distributed based on the allocation formula by taking into account the condition of the Village, one of the causes of poverty in the Village is limitations, even the absence of access and control of budget policies planned and established by the Village Government itself in alleviating poverty in the Village. Unfortunately there are still very few villages that are seriously working on poverty reduction programs. Nearly 90 percent of villages throughout Indonesia are more interested in financing easy physical development programs in planning and implementation. Even physical development programs are mentioned as a solution to poverty reduction.

Village Laws No. 6 of 2014 concerning Villages mandates that village development aims to among other things promote the economy of the village community, overcome the development gap, and strengthen the village community. In an effort to accelerate solving the problem of poverty, and inequality in the village, since the beginning of 2018 the President has stressed to Ministries / Agencies, Provincial Governments, District / City Governments, and Village Governments to implement Cash for Work programs in all villages .

Cash Work Solid is a program of village community empowerment activities for the poor and marginal communities, which are productive. This activity prioritizes the use of resources, labor, and technology Local technology to provide additional wages, reduce poverty, and improve people's welfare.

However the Cash for Work program is not a program that only emphasizes the existence of projects that can absorb the workforce of many people, but must also have a clear foundation for why a work project is carried out in a village. 
Salubua Village as well as Villages throughout Indonesia, prioritize Village development programs with the perception of alleviating poverty more quickly than budgeting in community empowerment programs, given the geographical condition of the remote village of Salubua, it is natural to prioritize the construction of road, bridge, drainage and village infrastructure. . However, the Village Government must continue to think about poverty alleviation along with the improvement of road and bridge infrastructure.

Through cash-intensive programs, the problem of poverty alleviation by opening employment in the village through community empowerment can solve one by one the problems of poverty in the village. Although not a final settlement, at least with cash-intensive Village communities earning income from development planned and proposed through village meetings.

Based on the Joint Decree (SKB) of 4 Ministers, namely Minister of Rural Development and Transmigration, Minister of Finance, Minister of PPN / Bappenas, and Minister of Home Affairs, on 18 December 2017 one of them contained the use of Village Funds for Solid Cash Work in the Village for activities Village development, where at least $30 \%$ must be used to pay community wages in order to create jobs in the Village. But the discourse was responded differently by the Head of the Salubua Village, according to his statement which was the epoche as below:

"Labor intensive can increase the income of the village community but it is not the final solution to poverty alleviation, I do not want the people of my village to be" laborers "in their own village"

Poverty alleviation program through the Cash Work Solid Program in the Village in the context of Village development activities, of which at least $30 \%$ must be used to pay community wages in order to create employment in the Village (noema). Not only relying on daily wages from the Cash for Work program, the Village Head wants more than just wages, the Village community, especially young people as the next generation must be able to independently support themselves and help their family's economy (noesis), starting from improving education and health levels. So that from the Village Head's statement above Eideitic reduction that the researcher can abstraction from the phenomenology study above is a form of manifestation of prosocial behavior by the Salubua Village Head in budgeting planning for poverty alleviation.

The Village Head acknowledged that this was not easy, and the road taken was still a long way to create young generations who were able to work independently, academic success followed by the ability to support themselves either by working properly or entrepreneurship opening employment opportunities in the village itself or overseas is not a problem, because the end of the impact of the success is sending financial assistance to his family which makes the economy turn around more alive, then transmits that success to the village, thus inspiring other young people to work hard to complete their education for a better life well.

\section{Conclusion:-}

Prosocial behavior is part of the value of the local wisdom of the Bastem community. This is based on the Bastem philosophy of life, namely "Tallo 'Manuk Sang Buriak; The Rapu Tallang; The 'Ivory' Kapoenan Awo, which means "A basket of chicken eggs, a cluster of bamboo / midfield, a group of yellow bamboo". This philosophy puts forward the attitude of helping and maintaining mutual integrity which is in line with the meaning of Prosocial Behavior, which is helping others selflessly and without coercion.

The results of further research indicate the meaning of Prosocial Behavior (Prosocial Behavior) of the Salubua village head in advancing the welfare of the community in fulfilling basic needs namely education, health, and poverty alleviation in the Village Fund budgeting, some of which are still constrained by village regulations and authority. The use of SILPA Funds in assisting the construction of Vocational High Schools is a prosocial form of the Head of Salubua in improving education even though there are no explicit rules governing the use of SILPA Funds, but the Head of Salubua considers the development of SMK important as fulfilling the basic needs of the people to receive proper education from government. So that based on the problems in the village of Salubua, the priority of the use of Village Funds set by the central government has not been able to be used maximally according to the village typology, it needs an in-depth study of potential, the uniqueness and vulnerability of the village in channeling Village Funds so that the principle of equitable distribution in the distribution of Village Funds can be achieved. 


\section{Bibliography:-}

1. Creswell,J.A. 2015. Penelitian Kualitatif dan Desain Riset. Yogyakarta. Pustaka Pelajar.

2. Dakelan., Huda,Miftahul., Haris,A.M., Dahlan,Aji. 2016. Mewujudkan Desa Inklusif. Jakarta : Direktorat Jendral Pendidikan Agama Kementerian Agama Republik Indonesia

3. Damayanti AR. 2010. Hubungan Keagenan Pemda Dalam Konteks Anggaran: Sebuah Agenda Rekonstruksi. Publikasi Ilmiah. Universitas Brawijaya. Malang

4. Damayanti AR., Syarifuddin., Darmawati., Indrijawati,Aini. 2012. Rekonstruksi Akuntabilitas : Sebuah Tinjauan Akuntansi dan Sistem Informasi dari Perspektif Lokal. Ekuitas : Jurnal Ekonomi dan Akuntansi No.80

5. Eko,S., Putra S. A., Akhmadin, M., Suhirman, Prayitni, H., Suryana,N., Mustakim, Z. 2016. Dana Desa untuk Desa Membangun Indonesia (Tanya Jawab Seputar Dana Desa). Jakarta: Kementerian Desa, Pembangunan Daerah Tertinggal, dan Transmigrasi Republik Indonesia

6. Eko,Sutoro. 2014. Desa Membangun Indonesia. Yogyakarta : Forum Pengembangan Pembaharuan Desa.

7. Hamdat,M.A. 2016. Pengkajian Nilai-Nilai Kearifan Lokal Berkenaan dengan Pengelolaan Lingkungan Hidup Komunitas Adat Terpencil di Sinaji Kecamatan Bastem Kabupaten Luwu. Makassar: Dinas Sosial Provinsi Sulawesi Selatan

8. Indonesian Corruption Watch. 2018. Outlook Dana Desa 2018: Potensi Penyalahgunaan Anggaran Desa di tahun Politik. Available from: https: //www.icw.go.id/id/publikasi

9. Mahayani. 2016. Prosocial Behaviour dan Persepsi Akuntabilitas Pengelolaan Dana Desa dalam Konteks Budaya Tri Hita Karana . Jurnal Ilmiah Akuntansi dan Bisnis. Vol XII No 2.

10. Mariana,D.,dkk. 2017. Desa: Situs Baru demokrasi Lokal. Yogyakarta: IRE

11. Nurcholis,H. 2017. Pemerintahan Desa Unit Pemerintahan Semu dalam Sistem Pemerintahan NKRI. Cetakan Ketiga. Jakarta. Bee Media Pustaka.

12. Mustakim,M.Z. 2015. Buku 2 Kepemimpinan Desa. Jakarta : Kementerian Desa, Pembangunan Daerah Tertinggal dan Transmigrasi Republik Indonesia

13. Peraturan Menteri dalam Negeri Nomor 113 Tahun 2014 tentang Pengelolaan Keuangan Desa. 2014 Jakarta: Menteri dalam Negeri

14. Pramesti, Siwi. 2015. KPK Temukan 14 Potensi Masalah Pengelolaan Dana Desa. (http://nasional.sindonews.com/read/1012030/13/kpk-temukan-14-potensi-masalah-pengelolaan-dana-desa1434116438) diakses pada 12 Januari 2018

15. Sopana, Ana. 2014. Kearifan Lokal Dalam Pusaran Modernitas (Studi Kasus: Partisipasi Masarakat Suku Tengger dalam Proses Penganggaran). Publikasi Ilmiah. Universitas Widyagama. Malang

16. Sopana, Ana. 2017. Proses Penganggaran Daerah berbasis Kearifan Lokal. Malang: Universitas Widyagama Malang

17. Suartana, I Wayan. 2010. Akuntansi Keprilakuan: Teori dan Implementasi. Offset Andi. Yogyakarta.

18. Syarifuddin. 2018. Dramaturgi Anggaran Pemerintah Daerah. Makassar: Phinatama Media

19. Syarifuddin. 2009. Konstruksi Kebijakan Anggaran : Aksentuasi Drama Politik dan Kekuasaan (Studi Kasus Kabupaten Jembrana Bali). Ekuitas : Jurnal Ekonomi dan Keuangan No. 110.

20. Undang-Undang Nomor 6 Tahun 2014 tentang Desa. 2014. Jakarta: Menteri Hukum dan Hak Asasi Manusia Republik Indonesia. 